\title{
Isolation and Synthesis of Tryptamine Derivatives from a Symbiotic Bacterium Xenorhabdus nematophilus PC
}

\author{
Seunguk Paik," Myung Kwang Park, Seong Hoon Jhun, Heai Ku Park, Chun Soo Lee, \\ Bum Rae Cho, Hong Sik Byun, Seok Burm Choe, and Seong Il Suh ${ }^{\dagger}$ \\ Faculty of Chemical \& Materials Engineering, Keimyung University, Daegu 704-701, Korea \\ ${ }^{\dagger}$ Department of Microbiology, School of Medicine, Keimyung University, Daegu 704-701, Korea \\ Received March 3, 2003
}

\begin{abstract}
Nematophin and its analog incorporating tryptamine unit have been isolated and characterized from strain XRPC of a symbiotic bacterium Xenorhabdus nematophilus, which was newly isolated from Korean entomopathogenic nematodes. The stereoselective synthesis of these compounds was accomplished, and the relative configurations were determined. Nematophin exhibited potent antibacterial activities over several strains of methicillin-resistant $S$. aureus (MRSA) comparable to those of vancomycin.
\end{abstract}

Key Words : Xenorhabdus nematophilus, Staphylococcus aureus, Nematophin, Tryptamine, L-Isoleucine

\section{Introduction}

In recent years, there has been much interest in bacteria of the genus Xenorhabdus since they were successfully used in the biological control of pest insects and a search for biologically active natural products. ${ }^{1}$ Xenorhabdus spp. are symbiotically associated with soil-dwelling, entomopathogenic nematodes of the genus Steinernema ${ }^{2}$ and has shown to be a rich source of several types of secondary metabolites exhibiting antibacterial, antineoplastic and/or antifungal activities. $^{3}$ The compounds previously reported from the bacterial genus Xenorhabdus include indole derivatives, ${ }^{4}$ xenorhabdins, ${ }^{5}$ hydroxystilbenes, ${ }^{6}$ water-soluble xenocoumacins $^{7}$ and anthraquinones. ${ }^{6}$

In the course of our studies on the secondary metabolites from five strains of Xenorhabdus nematophilus symbiotic to Korean entompathogenic nematodes of the genus Steinernema, we recently described the isolation and characterization of the unusual cytotoxic phenethylamides from the XR-NC strain of Xenorhabdus nematophilus. ${ }^{8}$ Continued investigation on bioactive constituents among microbial metabolites from another XR-PC strain of X. nematophilus have led to the finding of nematophin ${ }^{4}$ and its analog bearing indole moiety as the major constituents. We describe herein the isolation, bioactivity and synthesis of the indole derivatives from an insect-pathogenic bacterium newly isolated from the Korean entomopathogenic nematodes.

\section{Results and Discussion}

A symbiotic bacterium was isolated from entomopathogenic nematode Steinernema carpocapsae obtained from a soil sample collected at Pocheon located in the middle of the Korean Peninsula, and identified as Xenorhabdus nematophilus strain XR-PC. ${ }^{9}$ The cell-free broth of the mass cultured $X$. nematophilus was extracted with ethyl acetate. The organic extract was subjected to flash chromatography on $\mathrm{C}-18$, and the fractions eluted with $50 \%$ and $75 \% \mathrm{MeOH}$ were separated by reverse-phase HPLC to afford two antibiotic indole derivatives $\mathbf{1}$ and $\mathbf{2 a}$.

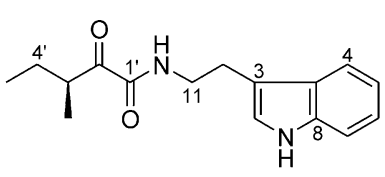

1

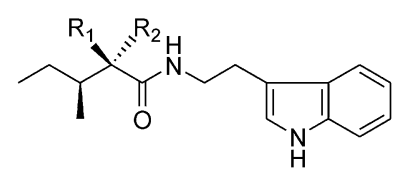

2a: $\mathrm{R}_{1}=\mathrm{H}, \mathrm{R}_{2}=\mathrm{OH}$ 2b: $\mathrm{R}_{1}=\mathrm{OH}, \mathrm{R}_{2}=\mathrm{H}$
Gross Structure. Compound 1, the major constituent of the organic extract, had a molecular formular of $\mathrm{C}_{16} \mathrm{H}_{20} \mathrm{~N}_{2} \mathrm{O}_{2}$ as established by HREIMS and NMR spectral data. The ${ }^{1} \mathrm{H}$ NMR spectrum of $\mathbf{1}$ showed six downfield protons [ $\delta 8.07$ $(1 \mathrm{H}$, br s, NH), $7.61(1 \mathrm{H}, \mathrm{d}, J=8.0 \mathrm{~Hz}), 7.38(1 \mathrm{H}, \mathrm{d}, J=8.4$ $\mathrm{Hz}), 7.22(1 \mathrm{H}, \mathrm{td}, J=8.0,1.2 \mathrm{~Hz}), 7.13(1 \mathrm{H}, \mathrm{td}, J=8.0,1.2$ $\mathrm{Hz})$, and $7.04(1 \mathrm{H}, \mathrm{d}, J=2.4 \mathrm{~Hz})]$, reminiscent of a $3-$ substituted indole, which was supported by ${ }^{13} \mathrm{C}-\mathrm{NMR}$ and COSY data. The presence of two adjacent methylene signals $[\delta 3.64(2 \mathrm{H}, \mathrm{q}, J=6.8 \mathrm{~Hz})$ and $3.03(2 \mathrm{H}, \mathrm{t}, J=6.8 \mathrm{~Hz})]$, two methyl signals $[\delta 1.08(3 \mathrm{H}, \mathrm{d}, J=6.8 \mathrm{~Hz})$ and $0.88(3 \mathrm{H}, \mathrm{t}, J$ $=7.6 \mathrm{~Hz})]$, a multiplet methine signal $[\delta 3.50(1 \mathrm{H}, \mathrm{m})]$ and one methylene signal $[\delta 1.72(1 \mathrm{H}, \mathrm{m})$ and $1.39(1 \mathrm{H}, \mathrm{m})]$ was observed in the NMR spectra; the COSY data indicated secbutyl and aminoethyl $\left(\mathrm{NH}-\mathrm{CH}_{2}-\mathrm{CH}_{2}\right)$ moieties, the latter of which was directly linked to the indole ring at the position 3 . The inspection of the ${ }^{13} \mathrm{C}$ NMR and DEPT spectra revealed the presence of two carbonyl carbons ( $\delta 202.3$ and 160.0) which were assigned as skeletal carbons of $\alpha$-ketoamide by COSY and HMBC spectra. These data, coupled with comparison of data from the literature, were in good agreement with those reported for nematophin. ${ }^{4}$ Thus, compound $\mathbf{1}$ was established as 3-indoleethyl (3'-methyl-2'-oxo)pentanamide (nematophin).

Compound 2, a minor component of the organic extract, proved to had a molecular formular of $\mathrm{C}_{16} \mathrm{H}_{22} \mathrm{~N}_{2} \mathrm{O}_{2}$ as deduced from HREIMS and NMR spectral data. The ${ }^{1} \mathrm{H}$ NMR spectrum of $\mathbf{2}$ were very similar to that of $\mathbf{1}$ except for 

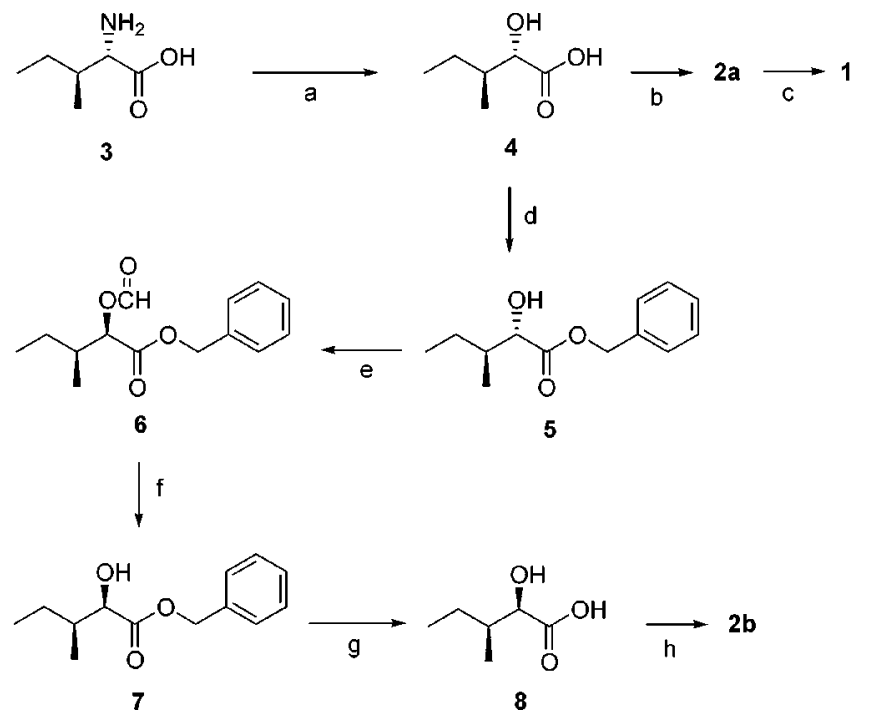

Scheme 1. Reagents and conditions: (a) $\mathrm{NaNO}_{2}, 0.5 \mathrm{M} \mathrm{H}_{2} \mathrm{SO}_{4}, 25$ ${ }^{\circ} \mathrm{C}, 24 \mathrm{~h}, 84 \%$ (b) DEPC, tryptamine, TEA, DMF, $0{ }^{\circ} \mathrm{C}$ to $25^{\circ} \mathrm{C}, 24$ h, $65 \%$ (c) Periodinane, $\mathrm{CH}_{2} \mathrm{Cl}_{2}, 25{ }^{\circ} \mathrm{C}, 1 \mathrm{~h}, 48 \%$ (d) $\mathrm{NaHCO}_{3}$, $\mathrm{H}_{2} \mathrm{O}$, aliquat $336, \mathrm{CH}_{2} \mathrm{Cl}_{2}$, benzyl bromide, $25^{\circ} \mathrm{C}, 2$ day, $90 \%$ (e) formic acid, $\mathrm{PPh}_{3}$, DIAD, THF, $0-25{ }^{\circ} \mathrm{C}, 2 \mathrm{~h}, 48 \%$ (f) $\mathrm{NH}_{4} \mathrm{OH}$, THF, $25{ }^{\circ} \mathrm{C}, 2 \mathrm{~h}, 83 \%$ (g) $10 \% \mathrm{Pd} / \mathrm{C}, \mathrm{MeOH}, 25{ }^{\circ} \mathrm{C}, 4 \mathrm{~h}, 91 \%$ (h) DEPC, tryptamine, TEA, DMF, $0-25{ }^{\circ} \mathrm{C}, 24 \mathrm{~h}, 62 \%$.

an additional methine signal $[\delta 3.93(1 \mathrm{H}, \mathrm{d}, J=3.2 \mathrm{~Hz}, \mathrm{H}-$ 2 ')], which was directly coupled to another methine proton $\left[\delta 1.82\left(1 \mathrm{H}, \mathrm{m}, \mathrm{H}-3^{\prime}\right)\right]$. The ${ }^{13} \mathrm{C}$ NMR spectrum revealed only one carbonyl carbon $(\delta 173.0)$, which suggested that $\alpha$ carbonyl group of $\alpha$-ketoamide functionality was converted to a carbon bearing a hydroxyl group $(\delta 2.35,1 \mathrm{H})$. These data, coupled with comparison of those from the literature, established the structure of compound $\mathbf{2}$ as the known nematophin derivative, N-(indol-3-ylethyl)-2'-hydroxy-3'methylpentanamide. ${ }^{4 \mathrm{~b}} \mathrm{Li}$ et al. proposed that the stereochemistry of the two asymmetric carbons in $\mathbf{2}$ was $2^{\prime} R, 3^{\prime} S$ on the bases of the ${ }^{1} \mathrm{H}$ NMR chemical shifts ${ }^{10}$ of $\mathrm{H}-3$ ' and $\mathrm{H}-4$ ' and L-isoleucine as a possible biosynthetic precursor.

Synthesis. A stereoselective synthesis of two diastereomers of $\mathbf{2}$ was carried out to establish the relative stereochemistry of the asymmetric carbons and to evaluate the biological activities on these synthetic derivatives. Our synthetic strategy using L-isoleucine as a chiral template was straightforward to prepare the diastereomers with antior syn-relative configuration (Scheme 1). L-Isoleucine was widely used as a starting material in natural product synthesis and its conversion to the corresponding 2-hydroxyisoleucic acid with retention of configuration has been well established in literature. ${ }^{11}$

The reaction of $(2 S, 3 S)$-isoleucine (4, L-isoleucine) with sodium nitrite in $0.5 \mathrm{M} \mathrm{H}_{2} \mathrm{SO}_{4}$ gave a diastereomeric mixture of the corresponding (2S,3S)-hydroxypentanoic acid $\mathbf{4}$, which was crystallized out from petroleum ether and ether to yield an optically pure white solid of $\mathbf{4}$ in $84 \%$ yield. Coupling of tryptamine with the unprotected hydroxy acid $\mathbf{4}$ was effected by means of DEPC method ${ }^{12}\left(\mathrm{DEPC} / \mathrm{Et}_{3} \mathrm{~N} /\right.$ DMF) to give 3 -indolylethyl amide 2a in $65 \%$ yield. The synthetic (2'S,3'S)-indolylethyl amide $\mathbf{2 a}$ was identical in all respects $\left({ }^{1} \mathrm{H}\right.$ and ${ }^{13} \mathrm{C}$ NMR, HPLC $\left.t_{R}\right)$ with the natural product. This result demonstrated that the relative configuration of $C^{\prime}-2$ and $C^{\prime}-3$ in the natural indolylethyl amide 2 ought to be anti $\left(2^{\prime} S^{*}, 3^{\prime} S^{*}\right)$ which was the opposite from $2^{\prime} R, 3 ' S$ conjectured by Lee and coworkers. ${ }^{4}$ Oxidation of $\mathbf{2 a}$ with Dess-Martin reagent (12-I-5) ${ }^{13}$ finally afforded ketoamide $\mathbf{1}$ in $48 \%$ yield; the PDC oxidation of $\mathbf{2 a}$ in DMF resulted in a low yield of $\mathbf{1}(<20 \%)$.

The synthesis of another diastereomeric $\mathbf{2 b}$ with 2 'S,3'S was accomplished by reaction of Mitsunobu inversion ${ }^{14}$ of the hydroxylic carbon of $\mathbf{4}$ via formate. Thus, benzyl ester $\mathbf{5}$ was prepared by alkylation of $\mathbf{4}$ with benzyl bromide under phase-transfer condition (aliquat $336,25^{\circ} \mathrm{C}, 90 \%$ ). In other to obtain $(2 R, 3 S)$-isomer, a Mitsunobu reaction was carried out with formic acid in the presence of triphenylphosphine and diisopropyl azodicarboxylate to furnish the desired $(2 R$, $3 S$ )-isomer 6 in $48 \%$ yield after chromatographic separation on silica gel. Ammonolysis of the formyl group in 6 with $25 \% \mathrm{NH}_{3}$ in THF selectively gave 7 in $83 \%$ yield. Catalytic hydrogenation of $\mathbf{7}$ in the presence of $\mathrm{Pd} / \mathrm{C}$ afforded the desired $(2 R, 3 S)$-isomer $8(91 \%)$, which was used in the next step without further purification. The ${ }^{1} \mathrm{H}$ NMR indicated that 8 was diasteromerically pure to the limits of detection (> 95\%). Coupling of tryptamine with 8 by DEPC method ${ }^{12}$ (DEPC/Et $3 \mathrm{~N} / \mathrm{DMF})$ gave $\left(2^{\prime} R, 3^{\prime} S\right)$-indolylethyl amide $\mathbf{2 b}$ (62\%), which showed different ${ }^{1} \mathrm{H}$ and ${ }^{13} \mathrm{C}$ NMR spectra from those of the natural indolylethyl amide. This result again indicated that the relative configuration of $C^{\prime}-2$ and $C^{\prime}-$ 3 in the natural indolyl amide 2 was anti $\left(2^{\prime} S^{*}, 3^{\prime} S^{*}\right)$; however, we were not able to establish its absolute stereochemistry due to very limited amount of the compound obtained naturally. It is suggested that the structure of $\mathbf{2}$ should be (2'S,3'S)-N-(indol-3-ylethyl)-2'-hydroxy-3'-methylpentanamide (2a) based on the levorotatory property ${ }^{4 \mathrm{~b}}$ of the synthetic amide $2 \mathrm{a}\left([\alpha]_{\mathrm{D}}-3.22^{\circ}, \mathrm{c} 1.55, \mathrm{CHCl}_{3}\right)$ and a postulated biosynthesis derived from L-isoleucine as a hydroxy acid precursor. ${ }^{4}$

Biological Activity. The MTT bioassay ${ }^{15}$ of $\mathbf{1}$ and $\mathbf{2}$ exhibited no significant cytotoxicities against human cancer cell lines of gastric adenocarcinoma, cervical adenocarcinoma, hepatoblastoma, colon adenocarcinoma, and lung adenocarcinoma. However, nematophin 1 showed highly selective activity against the Gram positive bacterium Staphylococcus aureus as reported by $\mathrm{Li}$, et al. ${ }^{4 \mathrm{a}}$; no considerable activity of compounds $\mathbf{2 a}$ and $\mathbf{2 b}$ against S.aureus was observed. In addition, compound 1 exhibited

Table 1. Minimum Inhibitory Concentration $(\mu \mathrm{g} / \mathrm{mL})$ of $\mathbf{1}$ and $\mathbf{2 a}$ against selected bacterial species

\begin{tabular}{lcccc}
\hline \multicolumn{1}{c}{ Compound } & 1 & 2a & vancomycin \\
bacterium & & & & \\
\cline { 1 - 3 } Escherichia coli 078 & $>100.0$ & $>100.0$ & 100.0 \\
Pseudomonas aeruginosa 1592E & $>100.0$ & $>100.0$ & 100.0 \\
Salmonella typhimurium & $>100.0$ & $>100.0$ & 100.0 \\
Streptococcus pyogenes 308A & 50.0 & $>100.0$ & 0.391 \\
Staphylococcus aureus 285 & $0.781>100.0$ & 0.781 \\
Staphylococcus aureus 809 & $0.391>100.0$ & 0.781 \\
\hline
\end{tabular}


potent activities over several strains of methicillin-resistant S.aureus (MRSA), which were comparable to vancomycin.

\section{Experimental Section}

General Experimental Procedures. MS spectra $(70 \mathrm{eV})$ were obtained with a Jeol JMS-700 instrument. ${ }^{1} \mathrm{H}$ and ${ }^{13} \mathrm{C}$ NMR spectra were recorded on a Bruker DRX-400 using TMS as internal references. HPLC was conducted with a Rainin Dynamax SD-200 instrument equipped with a Rainin Dynamax UV-C detector. Optical rotations were obtained with an ATAGO POLAL-L polarimeter. Analytical TLC was performed using Merck silica gel $60 \mathrm{PF}_{254}$. Dimethylformamide was distilled from calcium sulfate at 40 Torr and was stored over $4-\mathrm{A}^{\circ}$ molecular sieves. Unless otherwise noted, materials were obtained from commercial suppliers and used without further purification.

Extraction and Isolation. The cell-free broth $(6 \mathrm{~L}, \mathrm{pH}=$ 8.2) of the cultured XR-PC strain of $X$. nematophilus was neutralized with conc. $\mathrm{HCl}$ and extracted with ethyl acetate $(1 \mathrm{~L} \times 3)$. After evaporation of the solvent, the crude extract (1.6 g) was flash chromatographed on a C-18 column (40 g of YMC-GEL, ODS, 120A) with $3: 1,1: 1,1: 3 \mathrm{H}_{2} \mathrm{O} /$ $\mathrm{MeOH}$ mixtures, $\mathrm{MeOH}$, and ethyl acetate to give five fractions (100 mL each). Fraction 3 was concentrated and then subjected to HPLC (Dynamax C-18, $5 \mu, 21 \times 250 \mathrm{~mm}$, $5 \mathrm{~mL} / \mathrm{min}$; UV detection at $254 \mathrm{~nm}$ ) using $70 \% \mathrm{MeOH}$ as an eluent to give 1 ( $c a .10 \mathrm{mg}$ ). Fraction 2 was concentrated and then subjected to HPLC under the same condition above. The fractions containing compounds $\mathbf{1}$ and $\mathbf{2 a}$ was further purified by semi-preparative reversed-phase HPLC (Dynamax $\mathrm{C}-18,2 \mu, 250 \times 10 \mathrm{~mm}, 5 \mathrm{~mL} / \mathrm{min}$; UV detection at 254 $\mathrm{nm})$ using an isocratic system of $70 \%$ aqueous $\mathrm{MeOH}$ to afford $1\left(c a .5 \mathrm{mg}, \mathrm{t}_{\mathrm{R}} 10.2 \mathrm{~min}\right)$ and $2 \mathrm{a}\left(c a .5 \mathrm{mg}, \mathrm{t}_{\mathrm{R}} 6.5 \mathrm{~min}\right)$.

Nematophin (1): IR (KBr) $\lambda_{\max } 3450,3400,2950,1700$, $1690,1520 \mathrm{~cm}^{-1} ;{ }^{1} \mathrm{H} \mathrm{NMR}\left(\mathrm{CDCl}_{3}, 400 \mathrm{MHz}\right) \delta 8.07(1 \mathrm{H}, \mathrm{br}$ s, NH), $7.61(1 \mathrm{H}, \mathrm{d}, J=8.0 \mathrm{~Hz}, \mathrm{H}-4), 7.38(1 \mathrm{H}, \mathrm{d}, J=8.4 \mathrm{~Hz}$, H-7), $7.22(1 \mathrm{H}, \mathrm{td}, J=8.0,1.2 \mathrm{~Hz}, \mathrm{H}-5), 7.13(1 \mathrm{H}, \mathrm{td}, J=8.0$, $1.2 \mathrm{~Hz}, \mathrm{H}-6), 7.04(1 \mathrm{H} \mathrm{d} J=2.4 \mathrm{~Hz}, \mathrm{H}-2), 7.06(1 \mathrm{H}, \mathrm{br} \mathrm{s}, \mathrm{NH})$, $3.64(2 \mathrm{H}, \mathrm{q}, J=6.8 \mathrm{~Hz}, \mathrm{H}-11), 3.50\left(1 \mathrm{H}, \mathrm{m}, \mathrm{H}-3^{\prime}\right), 3.03(2 \mathrm{H}, \mathrm{t}$, $J=6.8 \mathrm{~Hz}, \mathrm{H}-10), 1.72\left(1 \mathrm{H}, \mathrm{m}, \mathrm{H}-4^{\prime}\right), 1.39\left(1 \mathrm{H}, \mathrm{m}, \mathrm{H}-4^{\prime}\right), 1.08$ $\left(3 \mathrm{H}, \mathrm{d}, J=6.8 \mathrm{~Hz}, \mathrm{Me}-3^{\prime}\right), 0.88\left(3 \mathrm{H}, \mathrm{t}, J=7.6 \mathrm{~Hz}, \mathrm{H}-5^{\prime}\right) ;{ }^{13} \mathrm{C}$ NMR $\left(\mathrm{CDCl}_{3}, 100 \mathrm{MHz}\right) \delta 202.3\left(\mathrm{C}-2^{\prime}\right), 160.0\left(\mathrm{C}-1^{\prime}\right), 136.4$ (C-9), 127.1 (C-8), 122.3 (C-5), 122.0 (C-2), 119.6 (C-6), 118.6 (C-4), 112.5 (C-3), 111.2 (C-7), 40.3 (C-3'), 39.5 (C10), 25.4 (C-11), 25.1 (C-4'), 15.1 (Me-3'), 11.5 (C-5'); HREIMS 272.1522 (calcd for $\mathrm{C}_{16} \mathrm{H}_{20} \mathrm{~N}_{2} \mathrm{O}_{2} 272.1525$ ).

(2'S,3'S)-N-(Indol-3-ylethyl)-2'-hydroxy-3'-methylpentanamide (2a): IR (KBr) $\lambda_{\max } 3420,3350,2950,1630,1540$ $\mathrm{cm}^{-1} ;{ }^{1} \mathrm{H}$ NMR $\left(\mathrm{CDCl}_{3}, 400 \mathrm{MHz}\right) \delta 8.04(1 \mathrm{H}, \mathrm{br} \mathrm{s}, \mathrm{NH})$, $7.62(1 \mathrm{H}, \mathrm{d}, J=8.0 \mathrm{~Hz}, \mathrm{H}-4), 7.38(1 \mathrm{H}, \mathrm{d}, J=8.0 \mathrm{~Hz}, \mathrm{H}-7)$, $7.21(1 \mathrm{H}, \mathrm{td}, J=8.0,1.2 \mathrm{~Hz}, \mathrm{H}-5), 7.13(1 \mathrm{H}, \mathrm{td}, J=8.0,0.8$ $\mathrm{Hz}, \mathrm{H}-6), 7.04(1 \mathrm{H}, \mathrm{d}, J=2.0 \mathrm{~Hz}, \mathrm{H}-2), 6.41(1 \mathrm{H}, \mathrm{br} \mathrm{s}, \mathrm{NH})$, $3.93(1 \mathrm{H}, \mathrm{d}, J=2.8 \mathrm{~Hz}, \mathrm{H}-2), 3.65(2 \mathrm{H}, \mathrm{q}, J=6.4 \mathrm{~Hz}, \mathrm{H}-$ 11), $3.00(2 \mathrm{H}, \mathrm{m}, \mathrm{H}-10), 2.35(1 \mathrm{H}, \mathrm{d}, J=5.6 \mathrm{~Hz}, \mathrm{OH}), 1.82$ $\left(1 \mathrm{H}, \mathrm{m}, \mathrm{H}-3^{\prime}\right), 1.35\left(1 \mathrm{H}, \mathrm{m}, \mathrm{H}-4^{\prime}\right), 1.12\left(1 \mathrm{H}, \mathrm{m}, \mathrm{H}-4^{\prime}\right), 0.95$ $\left(3 \mathrm{H}, \mathrm{d}, J=6.8 \mathrm{~Hz}, \mathrm{Me}-3^{\prime}\right), 0.86\left(3 \mathrm{H}, \mathrm{t}, J=7.2 \mathrm{~Hz}, \mathrm{H}-5^{\prime}\right) ;{ }^{13} \mathrm{C}$
NMR $\left(\mathrm{CDCl}_{3}, 100 \mathrm{MHz}\right) \delta 173.0$ (C-1'), 136.5 (C-9), 127.4 (C-8), 122.3 (C-5), 122.0 (C-2), 119.5 (C-6), 118.7 (C-4), 113.1 (C-3), 111.3 (C-7), 76.4 (C-2'), 39.3 (C-11), 38.8 (C3'), 25.4 (C-10), 23.0 (C-4'), 15.6 (Me-3'), 11.8 (C-5'); HREIMS 274.1679 (calcd for $\mathrm{C}_{16} \mathrm{H}_{22} \mathrm{~N}_{2} \mathrm{O}_{2} 274.1681$ ).

(2S,3S)-2-Hydroxy-3-methylpentanoic Acid (4). To a cooled $\left(0{ }^{\circ} \mathrm{C}\right)$ solution of L-isoleucine $(9.8 \mathrm{~g}, 75 \mathrm{mmol})$ in $0.5 \mathrm{M} \mathrm{H}_{2} \mathrm{SO}_{4}(300 \mathrm{~mL})$ was added $\mathrm{NaNO}_{2}(31 \mathrm{~g}, 450 \mathrm{mmol})$ over a period of $1 \mathrm{~h}$. After $1 \mathrm{~h}$, the mixture was allowed to warm to $25{ }^{\circ} \mathrm{C}$ and then stirred for $24 \mathrm{~h}$. The resulting solution was extracted with ether $(3 \times 50 \mathrm{~mL})$. The combined organic extracts were dried over anhydrous $\mathrm{Na}_{2} \mathrm{SO}_{4}$, filtered, and concentrated in vacuo to give a yellow oil, which was crystallized from ether and petroleum ether to afford 5 (8.3 $\mathrm{g}, 84 \%)$ as a white solid; $\mathrm{mp} 54-57^{\circ} \mathrm{C}$; IR $(\mathrm{KBr}) \lambda_{\max } 3450$, $1700,1430 \mathrm{~cm}^{-1} ;{ }^{1} \mathrm{H} \mathrm{NMR}\left(\mathrm{CDCl}_{3}, 100 \mathrm{MHz}\right) \delta 4.19(1 \mathrm{H}, \mathrm{d}$, $J=3.6 \mathrm{~Hz}), 1.89(1 \mathrm{H}, \mathrm{m}), 1.44(1 \mathrm{H}, \mathrm{m}), 1.29(1 \mathrm{H}, \mathrm{m}), 1.03$ $(3 \mathrm{H}, \mathrm{d}, J=7.2 \mathrm{~Hz}), 0.93(3 \mathrm{H}, \mathrm{t}, J=7.6 \mathrm{~Hz}) ;{ }^{13} \mathrm{C} \mathrm{NMR}$ $\left(\mathrm{CDCl}_{3}, 400 \mathrm{MHz}\right) \delta 179.5,74.61,38.8,23.6,15.3,11.7$; $[\alpha]_{\mathrm{D}} 28.75\left(\mathrm{c} 4, \mathrm{CHCl}_{3}\right)$.

(2S,3S)-2-Hydroxy-3-methylpentanoic Acid Benzyl Ester (5). To a cooled $\left(0{ }^{\circ} \mathrm{C}\right)$ solution of $4(1 \mathrm{~g}, 7.57 \mathrm{mmol})$, $\mathrm{NaHCO}_{3}(0.64 \mathrm{~g}, 7.57 \mathrm{mmol})$, and aliquat $336(3.06 \mathrm{~g}, 7.57$ mmol) in $\mathrm{H}_{2} \mathrm{O}(10 \mathrm{~mL})$ was added dropwise a solution of benzyl bromide $(0.9 \mathrm{~mL}, 7.57 \mathrm{mmol})$ in $\mathrm{CH}_{2} \mathrm{Cl}_{2}(10 \mathrm{~mL})$ over a period of $30 \mathrm{~min}$. The mixture was allowed to warm to $25^{\circ} \mathrm{C}$ and then stirred for $72 \mathrm{~h}$. The mixture was extracted with $\mathrm{CH}_{2} \mathrm{Cl}_{2}(3 \times 10 \mathrm{~mL})$, dried over anhydrous $\mathrm{Na}_{2} \mathrm{SO}_{4}$, filtered, and concentrated in vacuo to afford a yellow oil, which was purified by silica gel chromatography $(4: 1 \mathrm{Hex} /$ EtOAc) to afford $1.5 \mathrm{~g}(90 \%)$ of $\mathbf{5}$ as a colorless oil; ${ }^{1} \mathrm{H}$ NMR $\left(\mathrm{CDCl}_{3}, 400 \mathrm{MHz}\right) \delta 7.35(5 \mathrm{H}, \mathrm{m}), 5.20(2 \mathrm{H}, \mathrm{ABq}, J$ $=12 \mathrm{~Hz}), 4.11(1 \mathrm{H}, \mathrm{m}), 3.03(\mathrm{OH}, \mathrm{d}, J=6.0 \mathrm{~Hz}), 1.82(1 \mathrm{H}$, m), $1.34(1 \mathrm{H}, \mathrm{m}), 1.12(1 \mathrm{H}, \mathrm{m}), 0.95(3 \mathrm{H}, \mathrm{d}, J=6.8 \mathrm{~Hz})$, $0.86(3 \mathrm{H}, \mathrm{t}, J=7.6 \mathrm{~Hz}) ;{ }^{13} \mathrm{C} \mathrm{NMR}\left(\mathrm{CDCl}_{3}, 400 \mathrm{MHz}\right) \delta 174.7$, 135.1, 128.5, 128.4, 128.3, 74.7, 67.0, 39.0, 23.6, 15.3, 11.6.

$(2 R, 3 S)$-2-Formyloxy-3-methylpentanoic Acid Benzyl Ester (6). To a cooled $\left(0{ }^{\circ} \mathrm{C}\right)$ solution of $4(0.70 \mathrm{~g}, 3.14$ $\mathrm{mmol})$ in anhydrous THF $(30 \mathrm{~mL})$ was added triphenyl phosphine $(0.99 \mathrm{~g}, 3.77 \mathrm{mmol})$ and diisopropyl azodicarboxylate $(0.63 \mathrm{~mL}, 3.20 \mathrm{mmol})$. After $5 \mathrm{~min}$ at $0{ }^{\circ} \mathrm{C}, 0.24 \mathrm{~mL}$ $(6.34 \mathrm{mmol})$ of anhydrous formic acid was added over 5 min, and the mixture was maintained for $10 \mathrm{~h}$. To the reaction mixture was added sequentially another portion of triphenyl phosphine (1.89 g), diisopropyl azodicarboxylate $(1.55 \mathrm{~mL})$ and formic acid $(0.42 \mathrm{~g})$ at $0{ }^{\circ} \mathrm{C}$. The mixture was stirred at $0{ }^{\circ} \mathrm{C}$ for $12 \mathrm{~h}$, allowed to slowly warm to $25^{\circ} \mathrm{C}$ over an additional $10 \mathrm{~h}$ and then quenched with water. The mixture was extracted with EtOAc $(3 \times 100 \mathrm{~mL})$, washed with saturated aqueous $\mathrm{NaCl}(50 \mathrm{~mL})$, dried over anhydrous $\mathrm{MgSO}_{4}$, filtered, and concentrated in vacuo. The isolated yellow oil was chromatographed on silica gel $(10: 1$ hexane/ ethyl acetate) to afford $0.38 \mathrm{~g}$ (48\%) of $\mathbf{6}$ as a colorless oil; ${ }^{1} \mathrm{H}$ NMR $\left(\mathrm{CDCl}_{3}, 400 \mathrm{MHz}\right) \delta 8.14(1 \mathrm{H}, \mathrm{s}), 7.40-7.26(5 \mathrm{H}$, $\mathrm{m}), 5.21(1 \mathrm{H}, \mathrm{d}, J=3.2 \mathrm{~Hz}), 5.20(2 \mathrm{H}, \mathrm{ABq}, J=12.4 \mathrm{~Hz})$, $2.01(1 \mathrm{H}, \mathrm{m}), 1.44(1 \mathrm{H}, \mathrm{m}), 1.29(1 \mathrm{H}, \mathrm{m}), 0.92(3 \mathrm{H}, \mathrm{d}, J=$ $6.8 \mathrm{~Hz}), 0.91(3 \mathrm{H}, \mathrm{t}, J=7.2 \mathrm{~Hz}) ;{ }^{13} \mathrm{C} \mathrm{NMR}\left(\mathrm{CDCl}_{3}, 100\right.$ 
MHz) $\delta 169.6,160.8,135.6,129.0,128.9,128.7,74.6,67.5$, $36.9,26.2,14.6,11.9$.

(2R,3S)-2-Hydroxy-3-methylpentanoic Acid Benzyl Ester (7). To a solution of 6 (150 mg, $0.60 \mathrm{mmol})$ in THF (3 $\mathrm{mL}$ ) was added $0.7 \mathrm{~mL}$ of ammonia water at $25{ }^{\circ} \mathrm{C}$. The mixture was stirred for $5 \mathrm{~h}$ and extracted with EtOAc $(3 \times 10$ $\mathrm{mL})$. The organic extracts were washed with saturated aqueous $\mathrm{NaCl}(50 \mathrm{~mL})$, dried over anhydrous $\mathrm{MgSO}_{4}$, filtered, and concentrated in vacuo to afford a yellow oil, which was then purified by silica gel chromatography $(9: 1$ $\mathrm{Hex} / \mathrm{EtOAc}$ ) to afford $0.11 \mathrm{~g} \mathrm{(83 \% )}$ of $\mathbf{7}$ as a colorless oil; ${ }^{1} \mathrm{H}$ $\mathrm{NMR}\left(\mathrm{CDCl}_{3}, 400 \mathrm{MHz}\right) \delta$ 7.34-7.42 $(5 \mathrm{H}, \mathrm{m}), 5.24(2 \mathrm{H}$, $\mathrm{ABq}, J=12 \mathrm{~Hz}), 4.27(1 \mathrm{H}, \mathrm{s}), 3.03(1 \mathrm{H}, \mathrm{s}, \mathrm{OH}), 1.87(1 \mathrm{H}$, $\mathrm{m}), 1.57(1 \mathrm{H}, \mathrm{m}), 1.34(1 \mathrm{H}, \mathrm{m}), 0.97(3 \mathrm{H}, \mathrm{t}, J=7.6 \mathrm{~Hz}), 0.83$ $(3 \mathrm{H}, \mathrm{d}, J=7.2 \mathrm{~Hz}) ;{ }^{13} \mathrm{C}$ NMR $\left(\mathrm{CDCl}_{3}, 100 \mathrm{MHz}\right) \delta 175.7$, 135.6, 129.1, 129.0, 128.8, 73.4, 67.7, 39.0, 26.4, 13.5, 12.2; HREIMS 222.1256 (calcd for $\mathrm{C}_{13} \mathrm{H}_{18} \mathrm{O}_{3} 222.1256$ ).

(2R,3S)-2-Hydroxy-3-methylpentanoic Acid (8). To a solution of $7(130 \mathrm{mg}, 0.59 \mathrm{mmol})$ in $\mathrm{MeOH}(5 \mathrm{~mL})$ was added a catalytic amount of $10 \% \mathrm{Pd} / \mathrm{C}$, and the mixture was stirred under $\mathrm{H}_{2}$ at $25{ }^{\circ} \mathrm{C}$ for $2 \mathrm{~h}$. The mixture was filtered and washed with ethanol. The filtrate was concentrated to dryness in vacuo to afford $70 \mathrm{mg}(91 \%)$ of $\mathbf{8}$ as a white solid, pure by ${ }^{1} \mathrm{H}$ NMR analysis, which was used without further purification. ${ }^{1} \mathrm{H}$ NMR $\left(\mathrm{CDCl}_{3}, 400 \mathrm{MHz}\right) \delta 4.25(1 \mathrm{H}, \mathrm{s})$, $1.90(1 \mathrm{H}, \mathrm{m}), 1.54(1 \mathrm{H}, \mathrm{m}), 1.35(1 \mathrm{H}, \mathrm{m}), 0.96(3 \mathrm{H}, \mathrm{t}, J=7.2$ $\mathrm{Hz}), 0.88(3 \mathrm{H}, \mathrm{d}, J=6.4 \mathrm{~Hz})$.

Synthesis of (2'S,3'S)-N-(Indol-3-ylethyl)-2'-hydroxy3'-methylpentanamide (2a). To a cooled $\left(0{ }^{\circ} \mathrm{C}\right)$ solution of $4(0.5 \mathrm{~g}, 3.78 \mathrm{mmol})$ in anhydrous DMF $(5 \mathrm{~mL})$ was added tryptamine $(0.73 \mathrm{~g}, 4.54 \mathrm{mmol})$, diethyl cyanophosphate (DEPC, $0.69 \mathrm{~mL}, 4.54 \mathrm{mmol})$ and triethyl amine $(0.63 \mathrm{~mL}$, $4.54 \mathrm{mmol}$ ). The reaction mixture was stirred for $2 \mathrm{~h}$, allowed to warm to $25^{\circ} \mathrm{C}$ and then maintained at this temperature for an additional $24 \mathrm{~h}$. Water $(10 \mathrm{~mL})$ was added, followed by extraction with ethyl acetate $(3 \times 10 \mathrm{~mL})$. The organic extracts were dried over anhydrous $\mathrm{Na}_{2} \mathrm{SO}_{4}$, filtered, and concentrated in vacuo to afford $0.75 \mathrm{~g}$ of a yellow residue which was purified by silica gel chromatography $(50: 1$ $\left.\mathrm{CHCl}_{3} / \mathrm{MeOH}\right)$ to yield $2 \mathrm{a}(0.68 \mathrm{~g}, 65 \%)$ as a white solid; mp $118-120{ }^{\circ} \mathrm{C} ;[\alpha]_{\mathrm{D}}-3.22^{\circ}$ (c $\left.1.55, \mathrm{CHCl}_{3}\right) .{ }^{1} \mathrm{H}$ and ${ }^{13} \mathrm{C}$ NMR data were identical to those of the natural product.

(2'R,3'S)-N-(Indol-3-ylethyl)-2'-hydroxy-3'-methylpentanamide (2b). To a cooled $\left(0{ }^{\circ} \mathrm{C}\right)$ solution of $8(100 \mathrm{mg}, 0.76$ $\mathrm{mmol})$ in anhydrous DMF (3 $\mathrm{mL})$ was added tryptamine (149 mg, $0.91 \mathrm{mmol}$ ), diethyl cyanophosphate (DEPC, 0.16 $\mathrm{mL}, 0.91 \mathrm{mmol})$ and triethyl amine $(0.13 \mathrm{~mL}, 0.91 \mathrm{mmol})$. The reaction mixture was stirred for $2 \mathrm{~h}$, allowed to warm to $25{ }^{\circ} \mathrm{C}$ and then maintained at this temperature for $24 \mathrm{~h}$. Water $(5 \mathrm{~mL})$ was added, followed by extraction with ethyl acetate $(3 \times 5 \mathrm{~mL})$. The combined organic extracts were dried over anhydrous $\mathrm{Na}_{2} \mathrm{SO}_{4}$, filtered, and concentrated in vacuo to afford $0.15 \mathrm{~g}$ of a yellow residue which was purified by silica gel chromatography $\left(50: 1 \mathrm{CHCl}_{3} / \mathrm{MeOH}\right)$ to yield $2 \mathbf{b}(0.13 \mathrm{~g}, 62 \%)$ as a white solid; $\mathrm{mp} 137-140{ }^{\circ} \mathrm{C}$; ${ }^{1} \mathrm{H}$ NMR $\left(\mathrm{CDCl}_{3}, 400 \mathrm{MHz}\right) \delta 8.17(1 \mathrm{H}$, br s, NH), 7.61 $(1 \mathrm{H}, \mathrm{d}, J=8.0 \mathrm{~Hz}), 7.36(1 \mathrm{H}, \mathrm{d}, J=8.0 \mathrm{~Hz}), 7.20(1 \mathrm{H}, \mathrm{td}, J$
$=8.0,1.2 \mathrm{~Hz}), 7.12(1 \mathrm{H}, \mathrm{td}, J=8.0,1.2 \mathrm{~Hz}), 7.01(1 \mathrm{H}, \mathrm{d}, J=$ $2.0 \mathrm{~Hz}), 6.56(1 \mathrm{H}, \mathrm{br} \mathrm{s}, \mathrm{NH}), 4.02(1 \mathrm{H}, \mathrm{t}, J=2.8 \mathrm{~Hz}), 3.63$ $(2 \mathrm{H}, \mathrm{q}, J=6.4 \mathrm{~Hz}), 2.98(2 \mathrm{H}, \mathrm{m}), 2.60(1 \mathrm{H}, \mathrm{d}, J=5.6 \mathrm{~Hz}$, $\mathrm{OH}), 1.83(1 \mathrm{H}, \mathrm{m}), 1.42(1 \mathrm{H}, \mathrm{m}), 1.28(1 \mathrm{H}, \mathrm{m}), 0.91(3 \mathrm{H}, \mathrm{t}, J$ $=7.2 \mathrm{~Hz}), 0.77(3 \mathrm{H}, \mathrm{d}, J=7.2 \mathrm{~Hz}) ;{ }^{13} \mathrm{C} \mathrm{NMR}\left(\mathrm{CDCl}_{3}, 400\right.$ MHz) $\delta 173.0,136.5,127.4,122.3,122.0,119.6,118.7,113.1$, $111.3,76.4,39.4,38.9,25.5,23.2,15.5,11.8$; HRMS 274.1681 (calcd for $\mathrm{C}_{16} \mathrm{H}_{22} \mathrm{~N}_{2} \mathrm{O}_{2} 274.1681$ ); $[\alpha]_{D}+15.1^{\circ}$ (c $0.33, \mathrm{MeOH})$.

Nematophin (1): To a solution of 2 (100 $\mathrm{mg}, 0.36 \mathrm{mmol})$ in $\mathrm{CH}_{2} \mathrm{Cl}_{2}(5 \mathrm{~mL})$ was added $200 \mathrm{mg}(0.47 \mathrm{mmol})$ of DessMartin reagent (periodinane). The mixture was stirred for 20 min at $25^{\circ} \mathrm{C}$. The solution was filtered through Celite, and the solvent was removed under reduced pressure. The residue was subjected to silica gel chromatography with $2: 1$ $\mathrm{EtOAc} / \mathrm{CHCl}_{3}$ to give $48 \mathrm{mg}$ (48\%) of $\mathbf{1}$ as a white solid; mp 72-75 ${ }^{\circ} \mathrm{C} .{ }^{1} \mathrm{H}$ and ${ }^{13} \mathrm{C}$ NMR data were identical to those of the natural product.

Acknowledgment. The present research has been conducted by the attached research institute Research Grant of Keimyung University in 2000. This work was supported in part by Ministry of Science \& Technology (MOST) and the Korea Science and Engineering Foundation (KOSEF) through the Center for Traditional Microorganism Resources (TMR) at Keimyung University.

\section{References and Notes}

1. (a) Kaya, H. K.; Gauger, R. Ann. Rev. Entomol. 1993, 38, 261206. (a) Akhurst, R. J. J. Gen. Microbiol. 1982, 128, 3061-3065.

2. (a) Paul, V. J.; Frautschy, S.; Fenical, W.; Nealson, K. H. J. J. Chem. Ecol. 1981, 7, 589-597. (b) Forst, S.; Nealson, K. Microbiol. Rev. 1996, 60, 21-43.

3. (a) Maxwell, P. W.; Chen, G.; Webster, J. M.; Dunphy, G. B. Appl. Environ. Microbiol. 1994, 60, 715-721. (b) Chen, G.; Dunphy, G. B.; Webster, J. M. Biol. Control 1994, 4, 157-162.

4. (a) Li, J.; Chen, G.; Webster, J. M. Can. J. Microbiol. 1997, 43, 770-773. (b) Li, J.; Chen, G.; Webster, J. M. J. Nat. Prod. 1996, 59, 1157-1158. (c) Paul, V. J.; Frautschy, S.; Fenical, W.; Nealson, K. H. J. Chem. Ecol. 1981, 7, 589-597.

5. (a) Li, J.; Chen, G.; Webster, J. M.; Czyzewska, E. J. Nat. Prod. 1995, 58, 1081-1086. (b) McInerney, B. V.; Gregson, R. P.; Lacey, M. J.; Akhurst, R. J.; Lyons, G. R.; Rhodes, S. H.; Smith, D. R.; Engelhardt, L. M.; White, A. H. J. Nat. Prod. 1991, 54, 774-784.

6. Richardson, W. H.; Schmidt, T. M.; Nealson, K. H. Appl. Environ. Microbiol. 1988, 54, 1602-1605.

7. McInerney, B. V.; Taylor, W. C.; Lacey, M. J.; Akhurst, R. J.; Gregson, R. P. J. Nat. Prod. 1991, 54, 785-795.

8. Paik, S.; Park, Y. H.; Suh, S. I.; Kim, H. S.; Lee, I. S.; Park, M. K.; Lee, C. S.; Park, S. H. Bull. Korean Chem. Soc. 2001, 22, 372-374.

9. Park, S. H.; Yu, Y. S. Biotechnol. and Bioprocee Eng. 1999, 4, $12-16$.

10. Crombie, L.; Horsham, M. A.; Jarrett, S. R. M. J. Chem. Soc., Perkin Trans. 1 1991, 1511-1524.

11. (a) Irie, H.; Matsumoto, K.; Kitagawa, T.; Zhang, Y.; Ueno, T.; Nakashima, T.; Fukami, H. Chem. Pharm. Bull. 1987, 35, 25982601. (b) Degerbeck, F.; Fransson, B.; Grehn, L.; Ragnarsson, U. J. Chem. Soc. Perkin Trans. 1 1993, 11-14. (c) Schmidt, U.; Kroner, M.; Griesser, H. Synthesis 1989, 832-835.

12. Yamada, S.; Kasai, Y.; Shioriri, T. Tetrahedron Lett. 1973, 1595.

13. Dess, D. B.; Martin, J. C. Org. Chem. 1983, 48, 4155-4156.

14. Mitsunobu, O. Synthesis 1981, 1-28.

15. Twentyman, P.; Luscombe, M. Br. J. Cancer 1987, 56, 279-285. 